\title{
Implications of Different DEMs on Watershed Runoffs Estimations
}

\author{
Nazia N. Arbab1, Jean Marie Hartman², Johnny Quispe², Jason Grabosky ${ }^{1}$ \\ ${ }^{1}$ Department of Ecology, Evolution and Natural Resources, Rutgers University, New Brunswick, NJ, USA \\ ${ }^{2}$ Department of Landscape Architecture, Rutgers University, New Brunswick, NJ, USA \\ Email: nazia.arbab@rutgers.edu, jhartman@sebs.rutgers.edu, johnnyq@scarletmail.rutgers.edu, grabosky@sebs.rutgers.edu
}

How to cite this paper: Arbab, N.N., Hartman, J.M., Quispe, J. and Grabosky, J. (2019) Implications of Different DEMs on Watershed Runoffs Estimations. Journal of Water Resource and Protection, 11, 448-467. https://doi.org/10.4236/jwarp.2019.114027

Received: January 23, 2019

Accepted: April 27, 2019

Published: April 30, 2019

Copyright (๑) 2019 by author(s) and Scientific Research Publishing Inc. This work is licensed under the Creative Commons Attribution International License (CC BY 4.0).

http://creativecommons.org/licenses/by/4.0/

(c) (i) Open Access

\begin{abstract}
Watershed modelling tools like ArcSWAT, an ArcGIS extension of Soil and Water Assessment tool (SWAT), are useful to watershed managers in many ways. One particular use is analyzing model outputs for decision making related to waterway restoration and mitigation, which is often undertaken to improve water quality in streams. The present study evaluates the use of digital elevation model (DEM) at 10 meter, 30 meter, and 100 meter pixel size on non-point runoff predictions for three sub-watersheds in Raritan River Basin in New Jersey. These three watersheds include: Bound Brook, Lamington River, and Lawrence Brook watersheds. ArcSWAT is utilized to investigate the difference due to DEM variation in predicting monthly estimates of pollutant loads including ammonium $\left(\mathrm{NH}_{4}\right)$, nitrite $\left(\mathrm{NO}_{2}\right)$ and sediment transported with water out of a watershed. Using land use/cover, slope and soil data for 2012, monthly pollutant loads are calculated for each sub-basin in the watershed over a 10-year simulation period (2012-2022) in ArcSWAT. Overall statistical and spatial results show that ArcSWAT results are sensitive to changes in DEM pixel size for watershed modeling. The results show that total sum of monthly runoffs including $\mathrm{NH}_{4}, \mathrm{NO}_{2}$ and sediment differ among the three different DEMs. Moreover, the spatial pattern of input (in sub-catchments) also changes among the three DEMs for most watersheds. This indicates that watershed managers need to supplement model predictions with field measurements before making substantial investments in stream restoration programs.
\end{abstract}

\section{Keywords}

Runoffs, DEM, SWAT, Stream Restoration, Watershed Characteristics, Watershed Modeling

\section{Introduction}

ArcSWAT is commonly used to estimate water quality outcomes under various 
land management practices within its corresponding watershed [1] [2] [3]. SWAT is developed by the USDA Agricultural Research Service, is a continuous, distributed parameter, daily time step model used to assess the effects of land management practices on the hydrology, nutrients, sediments, and non-point source pollutant transport in watersheds under various slope, soils, and land use/cover conditions in a continuous-time framework [1] [4]. One of the functionalities of the SWAT model is to divide a watershed into sub-basins and then further divide each sub-basin into hydrological response units (HRUs). SWAT represents a realistic projection given specific biophysical features such as land use/cover, soil, topography, hydrology, climate, and policy effects at sub-watershed area [5].

In predicting surface runoff, the hydrological process requires determination of topographic characteristics [6]. The spatial patterns in such systems are heavily based upon the attributes such as slope and the area per slope length. DEMs are used as digital raster based map of the land surface area [6] [7]. DEMs are implemented as a topographic representation in ArcSWAT and serve as a crucial data layer to define physical parameters such as area, slope and slope length for each sub-basin within the watershed. The quality of the ArcSWAT model performance in predicting future scenarios depends upon how well the model inputs represent the relevant characteristics of the watershed. In general, there is a tradeoff between the DEM resolution and fine scale details for simulation, the accuracy of the data and computing speed [6]. Due to this tradeoff, users often select coarse resolution of DEM to speed up the simulations. It has been suggested that lower resolution in spatial input data results in segmented watersheds while higher resolution allows better delineation of flat surfaces [6] [8].

The quality of spatial input data is crucial for model development and accuracy [9]. Several studies analyzed the significance of scale effects on the quality of natural system processes and predictions [6] [8] [10] [11] [12]. Lin [13], analyzed the impact of different resolutions of DEMs. These DEMs are collected from different data sources to evaluate the sensitivity of SWAT output for three runoffs: sediment, total phosphorous (TP) and total nitrogen (TN). The results of their study suggest that SWAT is sensitive to the grid size effects due to the variations in DEM. The use of small grid size improves the model outcomes for 90 meter and 30 meter grid size but does not improve the results for 5 meter DEM. Another study investigated that difference in scales are minimal in small watershed, however in large scale watersheds there is an increased amount of uncertainty in stream flow outputs due to scale variation [11].

In ArcSWAT, multiple HRUs are calculated and generated based upon topography of the landscape. The HRUs derived through the use of DEM help in investigating the spatial variation in input, output, and flow of water pollutants in catchments [14] [15]. In order to capture the changes in watershed management on water quality outcomes, the model must reflect the quality and accuracy of such input data in the model [15]. Still, watershed managers use various DEMs in analyzing the watershed health under various stream restoration programs. 
To date, no such study existed for the Raritan River watershed to help watershed management to identify the suitable and efficient scale for predicting watershed quality outcomes. The Raritan River watershed's uniquely diverse activities and physiography make water resource management a complex issue to address and prove to be a challenge to state and local regulators working to maintain its integrity. This complex socio-ecological system consists of abiotic, biotic, and anthropogenic entities that provide a range of ecosystem services. In this regard, this paper investigates the impact of the three different cell sizes in the digital elevation model on simulated $\mathrm{NH}_{4}, \mathrm{NO}_{2}$ and sediment outputs of three watersheds: Bound Brook, Lamington River and Lawrence Brook watersheds of Rari$\tan$ River Basin in New Jersey by using the Soil and Water Assessment Tool (SWAT) in ArcGIS. The present study analyzed the sensitivity of ArcSWAT outputs on three DEM resolutions: $10 \mathrm{~m}, 30 \mathrm{~m}$ and $100 \mathrm{~m}$. The suitability and selection of these resolutions is based upon the results from several studies [9] [13] [16] [17] [18]. The relationship between resolution and runoff is important to understand the specific scale that is useful to achieve optimal results in simulation [19]. The literature of Raritan River Basin currently lacks methods for systematically analyzing the effect of grid size on statistical and spatial characterization of the land surface and associated hydrological response in terms of watershed quality parameters. The relationship between the hydrological spatial data input and associated hydrological response at different scales is not well understood. In this regard, the novelty of this paper is to provide the knowledge on scale assessment of elevation data in hydrological simulation.

The primary goal of this study is to demonstrate the sensitivity of the ArcSWAT model due to a change in topographic parameter and to provide a better understanding to assess the impacts of land surface variation due to flow direction changes with changing DEMs on surface water quality. Accordingly, the objective of this research is not only to project surface water quality outcome, but to provide an answer to a research question: if the change in resolution of surface patterns affecting water quality output in water quality modeling for small watersheds.

The following goals are met in order to achieve the primary objective of this study.

1) Use spatially determined surface changes to simulate impacts on the transport of $\mathrm{NH}_{4}, \mathrm{NO}_{2}$ and sediment in the selected sub-watersheds in Raritan River Watershed.

2) Analyze and compare the outcomes and relative importance of DEM of different sizes on surface water quality predictions of ArcSWAT.

\section{Methodology}

\subsection{Study Area}

The Raritan River Basin intersects three of New Jersey's physiographic regions- 
the Highlands, Piedmont, and Coastal Plain. Each of these regions has distinct geologic and soil characteristics. These characteristics affect soil drainage, surface water runoff, ground water recharge, and land use/cover development patterns throughout the Basin. The Raritan River Basin is a 1105 square mile drainage area and serves as an important source of drinking water for the central portion of New Jersey. Municipalities within the Raritan River Basin have been developing at a rapid pace, increasing the amount of impervious surface, reducing riverine buffers, and increasing storm water loads in rivers and streams which makes this a study system recognizable across the globe. Three sub watersheds as shown in Figure 1 were selected for analysis within the Raritan Basin: Bound Brook (Highly Urbanized), Lamington River (Mostly Forested), and Lawrence Brook (Moderately Urbanized and Forested).

\subsection{Input Data for ArcSWAT}

All the spatial input files including raster and polygon files are projected in NAD_1983_StatePlane_New_Jersey_FIPS_2900_Feet and 1:250,000 scale format is used.

\section{$D E M$}

DEM data for $100 \mathrm{~m}, 30 \mathrm{~m}$, and $10 \mathrm{~m}$ are collected for each watershed in the study area to compare runoff results for each grid size. $100 \mathrm{~m}$ and $30 \mathrm{~m}$ data are collected from National Elevation Dataset (NED) of U.S. Geological Survey (USGS) and 10 meter is collected from New Jersey Department of Environmental Protection (NJDEP).

\section{Land usel cover}

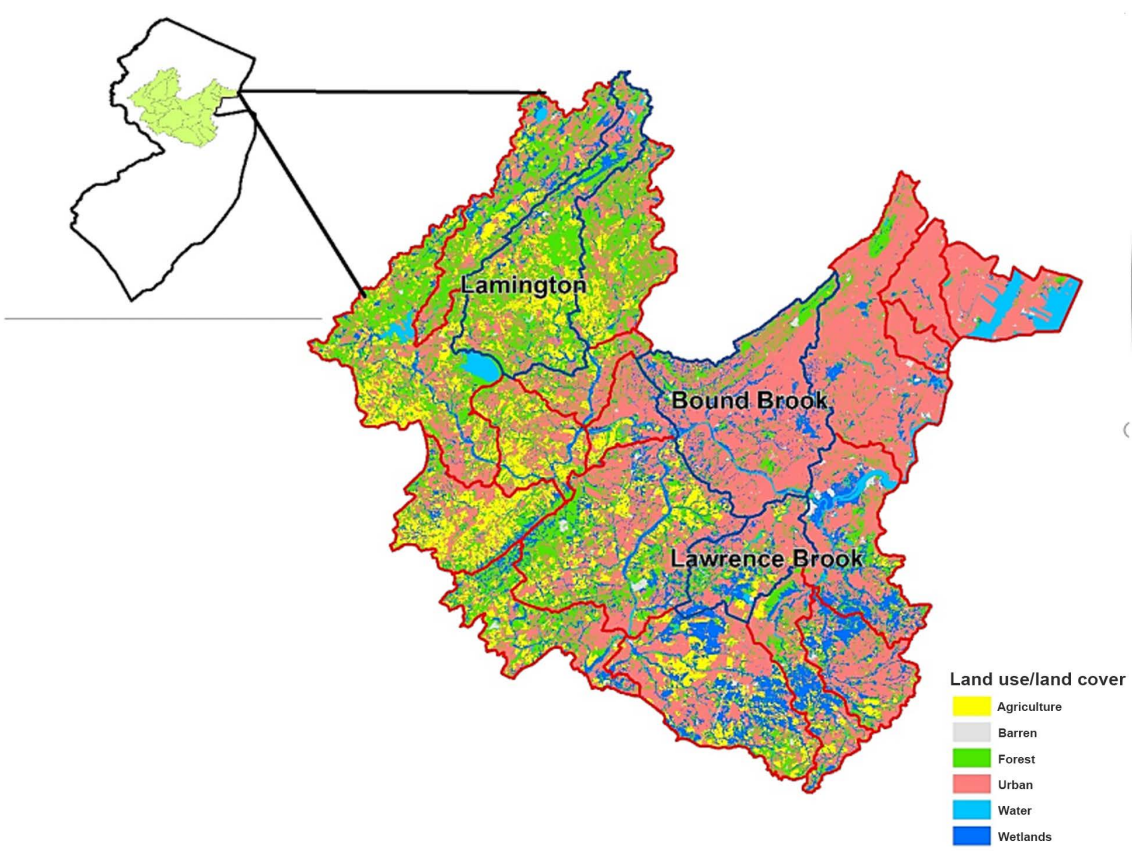

Figure 1. Land use/cover for the Raritan River watershed, New Jersey, 2012. Source: NJ Department of Environmental Protection (NJDEP), 2012. 
The most recent land use/cover data for the year 2012 is used and collected from New Jersey Department of Environmental Protection (NJDEP). The six land use/cover classes and their definitions utilized in the dataset are shown in Table 1 and Figures A1-A3 in Appendix.

\section{Streams}

Data on streams are delineated through the ArcSWAT Watershed delineation based on digital elevation model (DEM) raster for the Raritan River watershed. Three resolution of 100 meter, 30 meters, and 10 meters for each watershed are used for the elevation. ArcSWAT draws the location of the stream network based upon the flow direction and accumulation using DEM grid.

Soil

The Soil Survey Geographic (SSURGO) database is used in ArcSWAT in defining the HRUs. The SSURGO data is collected from USDA, NRCS, and New Jersey Office of Geographic Information Systems. SSURGO data provides smaller polygons (soil map units) and higher resolution with fine details. Each soil map unit represents a soil type in each watershed (Figures A1-A3 in Appendix).

\section{Slope}

In ArcSWAT multiple slope classes in percentage using 100 meter, 30 meter, and 10 meter DEMs are used to define the HRUs. The slope is broken down into four classes $(1 \%, 5 \%, 25 \%$ and more than $25 \%)$ to represent the variation in topography of the Raritan River watershed (Figures A1-A3 in Appendix).

\section{Weather Data}

Weather data are obtained from weather database from first order stations in ArcSWAT, which has the weather data from the year 1960 to 2010. The data on rainfall, temperature, relative humidity, solar radiation and wind speed are simulated using the weather generator function in ArcSWAT for each subbasin.

\subsection{ArcSWAT Model}

The ArcSWAT model processes overview is shown in Figure 2. The ArcSWAT model is set up using data on the three watersheds including: Bound Brook, Lamington River, and Lawrence Brook in Raritan River watershed, New Jersey. For each watershed 100, 30, and 10 meter resolution digital elevation model (DEM), land use/cover for 2012, soil type, and local meteorological conditions are used. A DEM is the input used to delineate the watershed sub-basins using topography, such as overland slope and slope length (in meters) to analyze the drainage patterns of the landscape and define the area of the sub-basin in the watershed. ArcSWAT delineated the physical characteristics of the watershed such as size, boundaries, and stream network based upon the digital elevation model (DEM), and divided the watershed into hydrologically and spatially connected sub-basins.

Using ArcSWAT, each of the three sub-watersheds is partitioned into sub-basins using sub-basin outlet locations. This division spatially connects each sub-basin 
Table 1. Land use/covers classes and their description ((NJDEP, 2012).

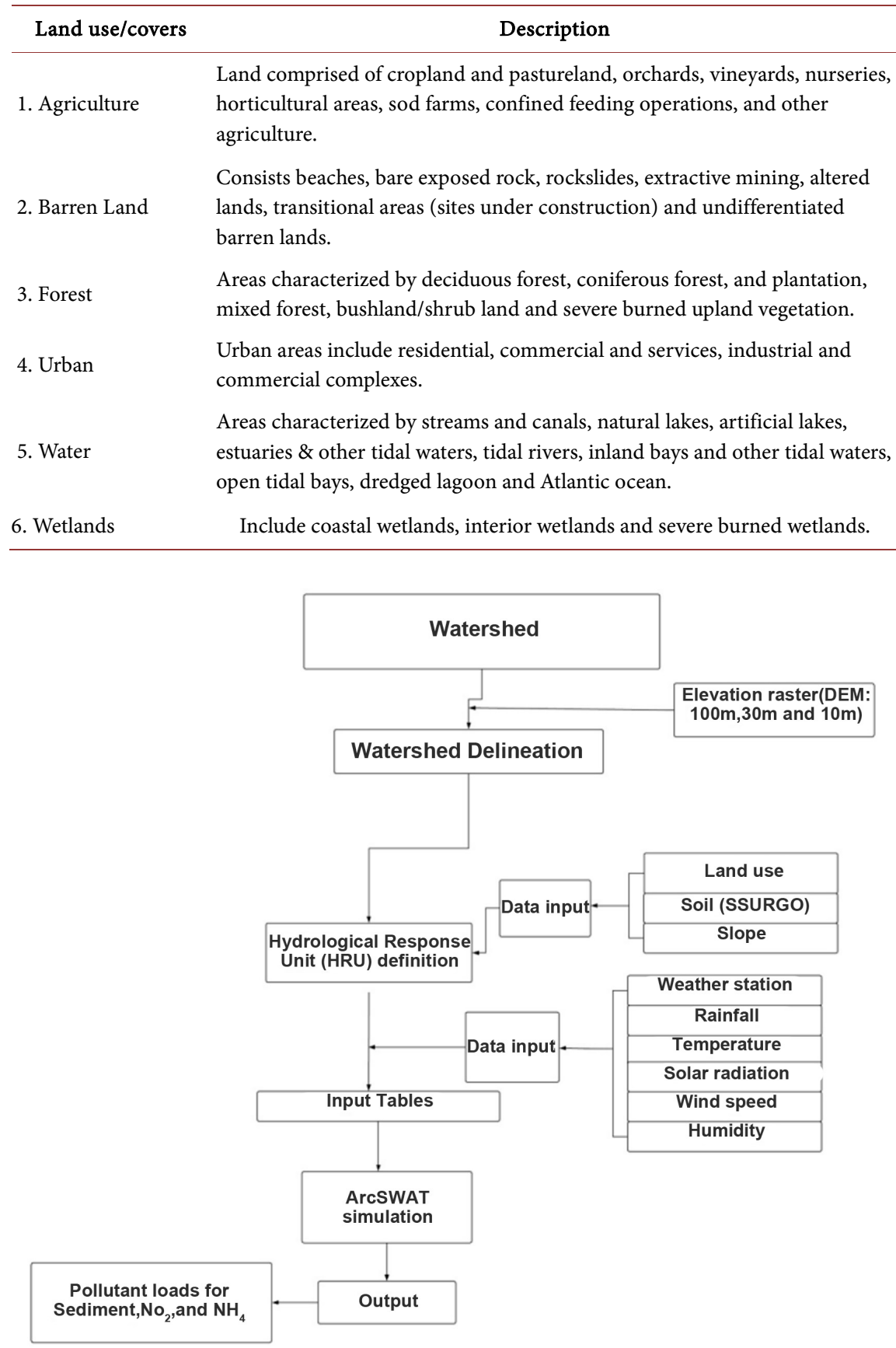

Figure 2. ArcSWAT model procedure for the Raritan River Watershed.

to one another [3]. Land use/cover classes are categorized accordingly to the SWAT code for each type of land use/cover as defined in Table 2.

The SSURGO soil data layer is prepared for each sub-watershed and used for the soil database in ArcSWAT. Once the land use/cover data, the SSURGO soil data, and the slope class layers are defined, the data is overlaid to derive unique subbasins. For the distribution of HRUs, multiple HRUs are used for this research. Each HRU in the watershed has a unique combination of land use/cover, 
Table 2. Land use/covers classes.

\begin{tabular}{cc}
\hline Land use/cover 2012 & SWAT land use/cover type \\
\hline 1. Agriculture & Agricultural land generic \\
2. Barren Land & Barren \\
3. Forest & Mixed forest \\
4. Urban & Residential urban areas \\
5. Water & Water \\
6. Wetlands & Mixed wetlands \\
\hline
\end{tabular}

soil type, and slope characteristics. Number of sub-basins are noted with each type of DEM.

ArcSWAT provides the weather database from local stations. ArcSWAT is run monthly over a 10 year time period. The pollutant loading data are extracted from model results. The selection criteria for runoff is the pollutant load releasing out of the watershed rather than the final pollutant load flowing into the watershed. Three pollutants: $\mathrm{NH}_{4}, \mathrm{NO}_{2}$ and sediment are selected from ArcSWAT output defined in Table 3.

ArcSWAT estimates the sediment yield in each sub basin using the (MUSLE) Modified Universal Soil Loss Equation (1) [20] [21]:

$$
\operatorname{Sed}=11.8 \cdot\left(Q_{\text {surf }} \cdot q_{\text {peak }} \cdot \operatorname{area}_{\text {hru }}\right)^{0.56} \cdot K_{\mathrm{USLE}} \cdot C_{\mathrm{USLE}} \cdot P_{\mathrm{USLE}} \cdot \mathrm{LS}_{\mathrm{USLE}} \cdot \mathrm{CFRG}
$$

where Sed is the sediment yield on a given day (metric tons), $Q_{\text {surf }}$ is the surface runoff volume $\left(\mathrm{mm} \mathrm{H}_{2} \mathrm{O} / \mathrm{ha}\right), q_{\text {peak }}$ is the peak runoff rate $\left(\mathrm{m}^{3} / \mathrm{S}\right)$, area hru $_{\text {hu }}$ is the area of the HRU (ha), $K_{\text {USLE }}$ is the USLE (Universal Soil Loss Equation) soil erodibility factor $\left(0.013\right.$ metric ton $\mathrm{m}^{2} \mathrm{hr} /\left(\mathrm{m}^{3}\right.$-metric ton $\left.\left.\mathrm{cm}\right)\right), C_{\mathrm{USLE}}$ is the USLE cover and management factor, $P_{\mathrm{USLE}}$ is the USLE support practice factor, LS $_{\text {USLE }}$ is the USLE topographic factor, and CFRG is the coarse fragment factor. The amount of sediment released out of the watershed on a given day is regarded as a function of final concentration in ArcSWAT.

The sediment Outflow in ArcSWAT is calculated as Equation (2) [21]:

$$
\operatorname{sed}_{\text {flowout }}=\operatorname{conc}_{\text {sed,f }} \cdot V_{\text {flowout }}
$$

where $\operatorname{sed}_{\text {flowout }}$ is the amount of sediment released out of the water with outflow (metric tons), conc sed,f $_{\text {f }}$ is the final sediment concentration $\left(\mathrm{Mg} / \mathrm{m}^{3}\right)$, and $V_{\text {flowout }}$ is the volume of outflow from the impoundment $\left(\mathrm{m}^{3}\right.$ of water).

Having the sediment yield calculation, ArcSWAT calculates the amount of sediment released to the main channel as Equation (3) [21]:

$$
\operatorname{sed}=\left(\operatorname{sed}^{\prime}+\operatorname{sed}_{\text {stor }, i-1}\right) \cdot\left(1-\exp \left[\frac{- \text { surlag }}{t_{\text {conc }}}\right]\right)
$$

where sed is the amount of sediment discharged to the main channel on a given day (metric tons), sed' is the amount of sediment load generated in the HRU on a given day (metric tons), $\operatorname{sed}_{\text {stor }, i-1}$ is the sediment stored or lagged from the 
Table 3. Variables and definitions of pollutant loads in ArcSWAT.

\begin{tabular}{cr}
\hline Variable & Definition \\
\hline $\mathrm{NH}_{4}$ OUT & Ammonium transported with water out of reach during time step (kg N). \\
$\mathrm{NO}_{2}$ OUT & Nitrite transported with water out of reach during time step (kg N). \\
SED_OUT & Sediment transported with water out of reach during time step (metric tons). \\
\hline
\end{tabular}

previous day (metric tons), surlag is the surface runoff lag coefficent, and $t_{\text {conc }}$ is the time of concentration for the HRU (hrs).

In ArcSWAT, a regression model estimates loadings such as $\mathrm{NH}_{4}$ and $\mathrm{NO}_{2}$ as a function of impervious area, land use/cover, and rainfall. The general equation developed in ArcSWAT to predict loadings in watersheds is shown in Equation (4) $[21]:$

$$
Y=\frac{\beta_{0} \cdot\left(R_{\text {day }} / 25.4\right)^{\beta_{1}} \cdot\left(\mathrm{DA} . i m p_{\mathrm{tot}} / 2.59\right)^{\beta_{2}} \cdot\left(\mathrm{imp}_{\mathrm{tot}} \cdot 100+1\right)^{\beta_{3}} \cdot \beta_{4}}{2.205}
$$

where $Y$ is the total constituent load $(\mathrm{kg}), R_{\text {day }}$ is precipitation on a given day $\left(\mathrm{mm} \mathrm{H}_{2} \mathrm{O}\right), \mathrm{DA}$ is the HRU drainage area $\left(\mathrm{km}^{2}\right), \mathrm{imp}_{\text {tot }}$ is the function of the total area that is impervious, and the $\beta$ variables are regression coefficients. The conversion factors to implement metric units in equations are used: 25.4 $\mathrm{mm} /$ inch, $2.59 \mathrm{~km}^{2} / \mathrm{mi}^{2}$, and $2.205 \mathrm{lb} / \mathrm{kg}$. ArcSWAT assigns the annual precipitation to each sub-basin by aggregating the monthly precipitation from the weather generator data [21].

\subsection{Statistical Analysis}

Once the level of monthly $\mathrm{NH}_{4}, \mathrm{NO}_{2}$, and sediment are calculated for each watershed, the relative performance of $100 \mathrm{~m}, 30 \mathrm{~m}$ and $10 \mathrm{~m}$ DEMs is compared considering sum outputs, the minimum, maximum, mean, median, and standard deviation of pollutant runoff yields for each watershed. By using sum outputs of $\mathrm{NH}_{4}, \mathrm{NO}_{2}$, and sediment, difference and percentage difference are calculated for $100 \mathrm{~m}, 30 \mathrm{~m}$ and $10 \mathrm{~m}$ DEMs. By using three DEMs, descriptive statistics and spatial maps of runoffs for each watershed scenario are compared. As suggested in [22], the coefficients of variation (CV) are calculated to compare model efficiency using three DEM grid size. CV also serves as a sensitivity analysis of the model for comparison. CV is calculated as Equation (5):

$$
\mathrm{CV}=\frac{\sigma}{\mu}
$$

where $\sigma$ is the standard deviation and $\mu$ is a mean.

Estimation for monthly runoff of $\mathrm{NH}_{4}, \mathrm{NO}_{2}$ and sediment using the $30 \mathrm{~m}$ and $10 \mathrm{~m}$ DEMs are compared to a reference $100 \mathrm{~m}$ DEM for quality assessment of DEM results. Statistical assessment as suggested in [9] is performed to investigate the sensitivity of the DEM in the model. This has been achieved using various statistical parameters including the mean difference (MD), the mean absolute difference (MAD), and the root mean standard difference (RMSD) between 
$30 \mathrm{~m}$ and $10 \mathrm{~m}$ DEMs, and $100 \mathrm{~m}$ as a base DEM (Equations (6)-(8)).

$$
\begin{aligned}
\mathrm{MD} & =\frac{1}{n} \sum_{i=1}^{n}\left[\left(\mathrm{Var}^{*}-\operatorname{Var}_{100 \mathrm{~m}}\right]\right. \\
\mathrm{MAD} & =\frac{\sum_{i=1}^{n}\left|(\mathrm{Var})^{*}-\operatorname{Var}_{100 \mathrm{~m}}\right|}{n} \\
\operatorname{RMSD} & =\left\{\frac{1}{n} \sum_{i=1}^{n}\left[(\mathrm{Var})^{*}-\operatorname{Var}_{100 \mathrm{~m}}\right]^{2}\right\}^{0.5}
\end{aligned}
$$

Here, MAD, MD and RMSD decrease show increasing model accuracy across all DEMS. The RMSD represents the degree to which the value of $10 \mathrm{~m}$ and $30 \mathrm{~m}$ differs from the reference $100 \mathrm{~m}$ DEM value.

\section{Results}

The ArcSWAT estimated the monthly yield of $\mathrm{NH}_{4}, \mathrm{NO}_{2}$ and sediment over 10 year time period generated from the different resolutions of DEM combined with land use/cover and soil maps (Table 4). The total sum yield of sediment (tons/hectare) increased with $100 \mathrm{~m}$ for all watersheds. $\mathrm{NH}_{4}$ (kg/hectare) has mixed results showing increase for Lawrence Brook with $10 \mathrm{~m}$, Lamington River with $100 \mathrm{~m}$ and Bound Brook with $30 \mathrm{~m}$. Similarly $\mathrm{NO}_{2}$ (kg/hectare) has mixed results showing slight increase for Lawrence Brook with $30 \mathrm{~m}$, Lamington River with $10 \mathrm{~m}$ and Bound Brook with $100 \mathrm{~m}$ (Table 4). Overall, significant percentage difference was shown between $30 \mathrm{~m}$ and $100 \mathrm{~m}$ across all pollutants except $\mathrm{NH}_{4}$ for Bound Brook. This difference resulted due to different numbers of sub-basins with variation in DEMs for most sub-watersheds (Table 4). The impacts of DEM resolution on model efficiency are investigated using coefficient of variation (CV) (Tables 5-7). With three DEMs, fixed scales of land use/cover and soil maps $(1: 250,000)$ are used in ArcSWAT analysis. CV indicates how sensitive the model is to the DEM pixel size on which the runoffs are simulated in ArcSWAT. The results show the changes in value of CV. This indicates that the model is sensitive to the scale variation (Tables 5-7).

\begin{tabular}{|c|c|c|c|c|}
\hline Sub-watershed & \#of sub-basins & Sediment & $\mathrm{NH}_{4}$ & $\mathrm{NO}_{2}$ \\
\hline \multicolumn{5}{|l|}{ Lawrence Brook } \\
\hline Total Sum at $10 \mathrm{~m}$ & 25 & $171,541.77$ & $27,336.18$ & 411.74 \\
\hline Total Sum at $30 \mathrm{~m}$ & 24 & $155,469.05$ & $25,101.87$ & 414.14 \\
\hline Total Sum at $100 \mathrm{~m}$ & 26 & $293,419.9$ & $19,580.62$ & 226.90 \\
\hline Difference (10 m \& 30 m) & & $16,072.72$ & 2234.31 & 2.40 \\
\hline $\begin{array}{l}\% \text { difference }(10 \mathrm{~m} \& 30 \mathrm{~m}) \\
=10 \mathrm{~m}-30 \mathrm{~m} / 30 \mathrm{~m} \times 100\end{array}$ & & $10.34 \%$ & $8.90 \%$ & $-0.58 \%$ \\
\hline Difference $(30$ m \& 100 m) & & $137,950.85$ & -5521.25 & -187.24 \\
\hline$\%$ difference $(30 \mathrm{~m} \mathrm{\&} 100 \mathrm{~m})$ & & $-47.01 \%$ & $28.20 \%$ & $82.52 \%$ \\
\hline
\end{tabular}

Table 4. Total sum, difference, and \% difference in sediment, $\mathrm{NH}_{4}$, and $\mathrm{NO}_{2}$ in $10 \mathrm{~m}, 30$ m, and 100 m DEMs for Lawrence Brook, Lamington River, and Bound Brook. 


\section{Continued}

\begin{tabular}{|c|c|c|c|c|}
\hline Lamington River & & Sediment & $\mathrm{NH}_{4}$ & $\mathrm{NO}_{2}$ \\
\hline Total Sum at $10 \mathrm{~m}$ & 23 & $586,951.06$ & $29,195.65$ & 34.57 \\
\hline Total Sum at $30 \mathrm{~m}$ & 23 & $555,893.93$ & $26,179.36$ & 30.42 \\
\hline Total Sum at $100 \mathrm{~m}$ & 21 & $1,514,951$ & $30,267.38$ & 11.68 \\
\hline Difference $(10 \mathrm{~m} \& 30 \mathrm{~m})$ & & $31,057.13$ & 3016.30 & 4.14 \\
\hline$\%$ difference $(10 \mathrm{~m} \mathrm{\&} 30 \mathrm{~m})$ & & $5.59 \%$ & $11.52 \%$ & $13.61 \%$ \\
\hline \multicolumn{5}{|l|}{$=10 \mathrm{~m}-30 \mathrm{~m} / 30 \mathrm{~m} \times 100$} \\
\hline Difference $(30 \mathrm{~m} \& 100 \mathrm{~m})$ & & $959,057.07$ & 4088.02 & -18.74 \\
\hline$\%$ difference $(30 \mathrm{~m} \& 100 \mathrm{~m})$ & & $-63.31 \%$ & $-13.51 \%$ & $160.48 \%$ \\
\hline Bound Brook & & Sediment & $\mathrm{NH}_{4}$ & $\mathrm{NO}_{2}$ \\
\hline Total Sum at $10 \mathrm{~m}$ & 26 & $749,899.84$ & $87,756.30$ & 632.55 \\
\hline Total Sum at $30 \mathrm{~m}$ & 29 & $762,364.61$ & $95,237.21$ & 1538.94 \\
\hline Total Sum at $100 \mathrm{~m}$ & 32 & $1,537,139.59$ & $94,816.47$ & 2051.53 \\
\hline Difference (10 m \& $30 \mathrm{~m})$ & & 12464.80 & 7480.91 & 906.39 \\
\hline$\%$ difference $(10 \mathrm{~m} \& 30 \mathrm{~m})$ & & $-1.64 \%$ & $-7.86 \%$ & $-58.90 \%$ \\
\hline \multicolumn{5}{|l|}{$=10 \mathrm{~m}-30 \mathrm{~m} / 30 \mathrm{~m} \times 100$} \\
\hline Difference $(30 \mathrm{~m} \& 100 \mathrm{~m})$ & & $774,774.98$ & -420.73 & 512.59 \\
\hline $\begin{array}{l}\% \text { difference }(30 \mathrm{~m} \mathrm{\&} 100 \mathrm{~m}) \\
=30 \mathrm{~m}-100 \mathrm{~m} / 100 \mathrm{~m} \times 100\end{array}$ & & $-50.40 \%$ & $0.44 \%$ & $-24.99 \%$ \\
\hline
\end{tabular}

Table 5. Descriptive statistics of average monthly runoff for Bound Brook 10 meter, 30 meter and 100 meter DEM.

\begin{tabular}{|c|c|c|c|}
\hline Descriptive. Stats & Sediment & $\mathrm{NH}_{4}$ & $\mathrm{NO}_{2}$ \\
\hline \multicolumn{4}{|c|}{ Bound Brook 10 meter DEM } \\
\hline Min & 0.259 & 0.004 & 0.000 \\
\hline $\operatorname{Max}$ & 8431 & 662.8 & 11.29 \\
\hline Median & 106.6 & 2.706 & 0 \\
\hline Mean & 238.4 & 27.89 & 0.201 \\
\hline Standard Deviation & 437.357 & 56.765 & 0.909 \\
\hline Coefficient of variation & 1.835 & 2.035 & 4.522 \\
\hline \multicolumn{4}{|c|}{ Bound Brook 30 meter DEM } \\
\hline Min & 0.271 & 0.002 & 0 \\
\hline Max & 7183 & 602.3 & 28.38 \\
\hline Median & 89.03 & 2.647 & 0 \\
\hline Mean & 217.3 & 27.14 & 0.439 \\
\hline Standard Deviation & 387.041 & 53.944 & 2.030 \\
\hline Coefficient of variation & 1.781 & 1.988 & 4.624 \\
\hline \multicolumn{4}{|c|}{ Bound Brook 100 meter DEM } \\
\hline Min & 13.582 & 0.032 & 0.000 \\
\hline Max & 1099.648 & 145.846 & 9.099 \\
\hline
\end{tabular}




\section{Continued}

\begin{tabular}{cccc}
\hline Median & 275.864 & 1.957 & 0.000 \\
Mean & 331.280 & 20.435 & 0.442 \\
Standard Deviation & 292.108 & 36.789 & 1.686 \\
Coefficient of variation & 0.882 & 1.800 & 3.814 \\
\hline
\end{tabular}

Table 6. Descriptive statistics of average monthly runoff for Lamington River 10 meter, 30 meter, and 100 meter DEM.

\begin{tabular}{|c|c|c|c|}
\hline Descriptive. Stats & Sediment & $\mathrm{NH}_{4}$ & $\mathrm{NO}_{2}$ \\
\hline \multicolumn{4}{|c|}{ Lamington 10 meter DEM } \\
\hline Min & 0.077 & 0.007 & 0.000 \\
\hline $\operatorname{Max}$ & 5890.000 & 306.300 & 2.162 \\
\hline Median & 93.330 & 1.478 & 0.000 \\
\hline Mean & 210.900 & 10.490 & 0.012 \\
\hline Standard Deviation & 336.631 & 23.314 & 0.071 \\
\hline Coefficient of variation & 1.596 & 2.222 & 5.917 \\
\hline \multicolumn{4}{|c|}{ Lamington 30 meter DEM } \\
\hline Min & 0.075 & 0.007 & 0.000 \\
\hline Max & 5074 & 277.800 & 2.227 \\
\hline Median & 88.6 & 1.323 & 0 \\
\hline Mean & 199.700 & 9.407 & 0.011 \\
\hline Standard Deviation & 304.188 & 21.270 & 0.067 \\
\hline Coefficient of variation & 1.523 & 2.261 & 6.091 \\
\hline \multicolumn{4}{|c|}{ Lamington 100 meter DEM } \\
\hline Min & 65.630 & 0.071 & 0.000 \\
\hline Max & 1181.896 & 72.200 & 0.058 \\
\hline Median & 451.892 & 1.506 & 0 \\
\hline Mean & 497.521 & 9.407 & 0.004 \\
\hline Standard Deviation & 341.196 & 17.469 & 0.013 \\
\hline Coefficient of variation & 0.686 & 1.857 & 3.332 \\
\hline
\end{tabular}

Table 7. Descriptive statistics of average monthly runoff for Lawrence Brook 10 meter, 30 meter, and 100 meter DEM.

\begin{tabular}{cccc}
\hline Descriptive. Stats & Sediment & $\mathrm{NH}_{4}$ & $\mathrm{NO}_{2}$ \\
\hline \multicolumn{2}{l}{ Lawrence Brook 10 meter DEM } & & \\
Min & 0.038 & 0.001 & 0 \\
Max & 1551.000 & 151.700 & 0 \\
Median & 22.370 & 1.666 & 0.136 \\
Mean & 56.710 & 9.037 & 081 \\
\hline
\end{tabular}




\section{Continued}

\begin{tabular}{|c|c|c|c|}
\hline Standard Deviation & 100.391 & 15.939 & 0.564 \\
\hline Coefficient of variation & 1.770 & 1.764 & 4.147 \\
\hline \multicolumn{4}{|c|}{ Lawrence Brook 30 meter DEM } \\
\hline Min & 0.034 & 0.003 & 0.000 \\
\hline Max & 1089.000 & 137.000 & 8.863 \\
\hline Median & 22.460 & 1.602 & 0.000 \\
\hline Mean & 53.540 & 8.644 & 0.143 \\
\hline Standard Deviation & 85.851 & 14.775 & 0.580 \\
\hline Coefficient of variation & 1.603 & 1.709 & 4.056 \\
\hline \multicolumn{4}{|c|}{ Lawrence Brook 100 meter DEM } \\
\hline Min & 7.281 & 0.021 & 0.000 \\
\hline $\operatorname{Max}$ & 307.347 & 34.927 & 1.004 \\
\hline Median & 45.095 & 0.707 & 0.000 \\
\hline Mean & 77.830 & 5.194 & 0.060 \\
\hline Standard Deviation & 73.997 & 8.988 & 0.206 \\
\hline Coefficient of variation & 0.951 & 1.730 & 3.418 \\
\hline
\end{tabular}

Spatial patterns of pollutant loads for each sub-basin in the watershed over a 10 year simulation period also show variation in the distribution of pollutant runoffs among three sub-watersheds (Figures 3-5). DEM is the major spatial data input to assess the prediction of runoff and sediments in the watershed. Results show that spatial concentration pattern of $\mathrm{NH}_{4}, \mathrm{NO}_{2}$ and sediment have changed across DEMs in most watersheds (Figures 3-5). The spatial distribution of watershed pollutants across different sub basins shows DEMs influenced spatial patterns of pollutants by the changing DEM resolution effects.

Root mean square deviation focuses on overall relative measure of similarity of two maps of each DEM grid for pollutants in each watershed, allowing to assess the differences in spatial distribution. Selected results show with $100 \mathrm{~m}$ DEM the runoff of $\mathrm{NH}_{4}$ and $\mathrm{NO}_{2}$ is stretched out in the central-lower part of the Bound Brook watershed (Figure 3) with smooth topography, compared to the northern area exhibited relatively steeper slopes (Figure 3 \& Figure A1 in Appendix)

Having estimations of runoff of sediment, $\mathrm{NH}_{4}$, and $\mathrm{NO}_{2}$ over 2012-2022, ArcSWAT is used here as a decision tool to test the effect of the DEM on the mean monthly runoff of sediment, $\mathrm{NH}_{4}$ and $\mathrm{NO}_{2}$. Most of the results show some variation in runoff due to difference in DEMs. When 100m DEM used as a reference, mean difference (MD), mean absolute difference (MAD), and especially root mean square difference (RMSD) revealed a significant change in terms of model sensitivity in predicting sediment. The results show no variation in overall relative sensitivity with $\mathrm{NO}_{2}$ with change in DEMs (Tables 8-10). 

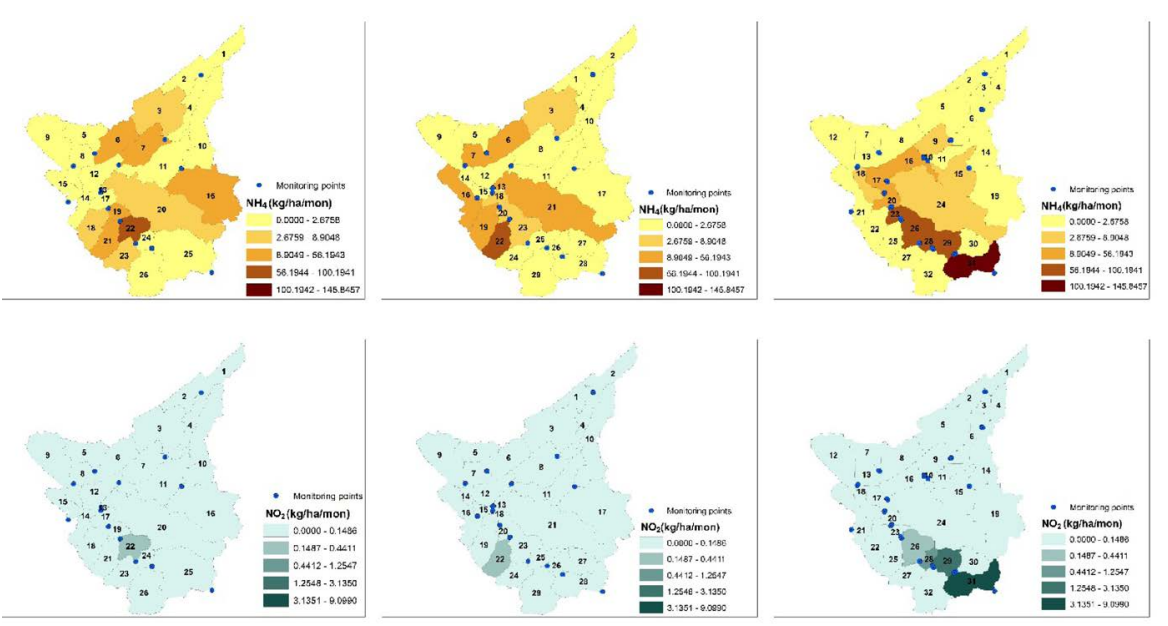

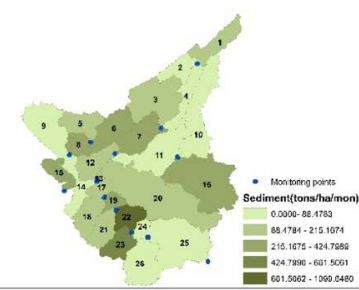

(a)

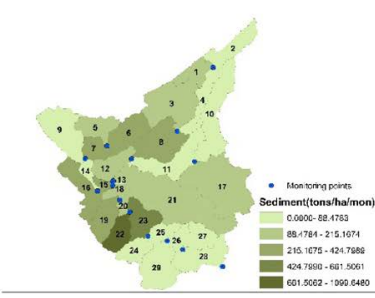

(b)

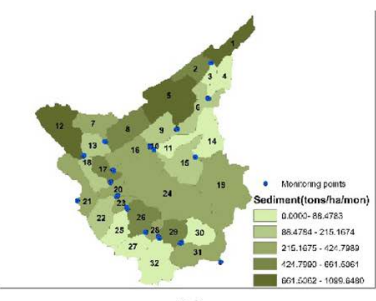

(c)

Figure 3. $\mathrm{NH}_{4}, \mathrm{NO}_{2}$ and sediment yields from each sub-basin as estimated by ArcSWAT. (a) Bound Brook 10 meter DEM; (b) Bound Brook 30 meter DEM; (c) Bound Brook 100 meter DEM.
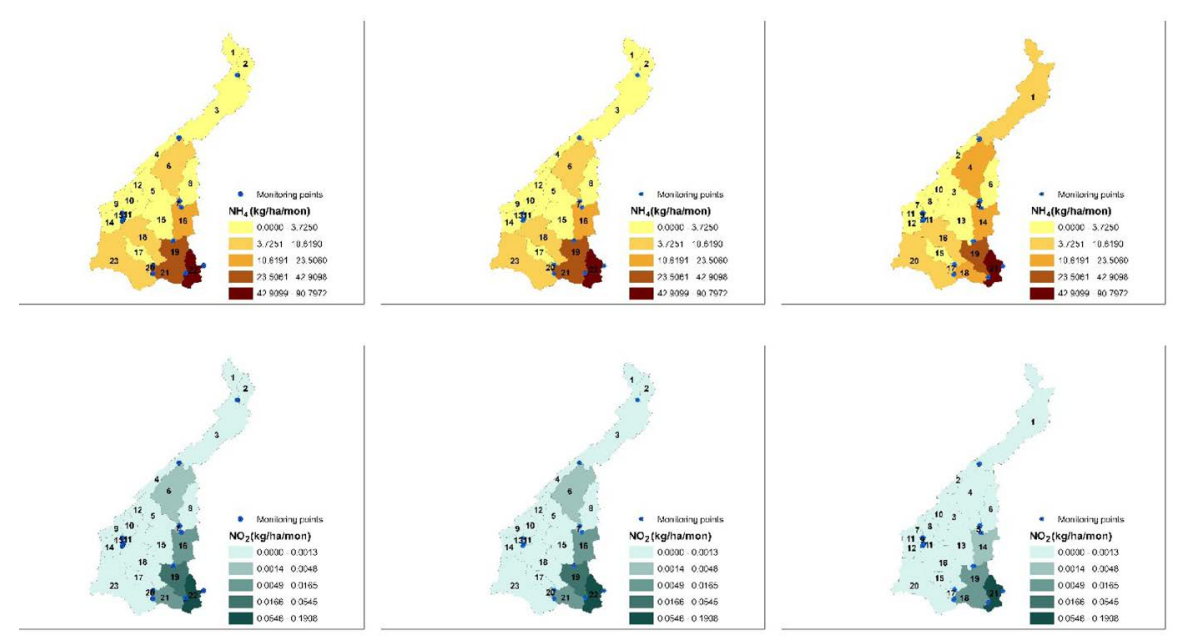

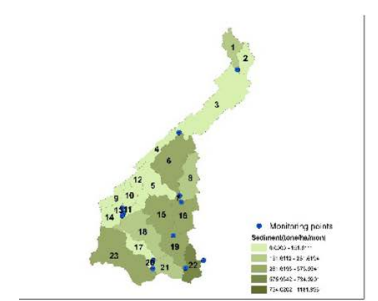

(a)

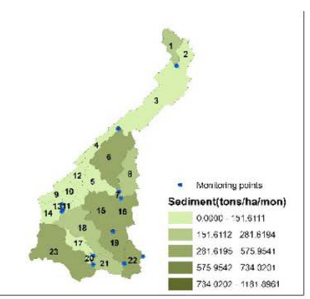

(b)

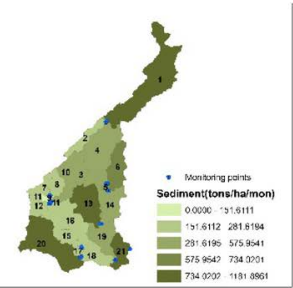

(c)

Figure 4. $\mathrm{NH}_{4}, \mathrm{NO}_{2}$ and sediment yields from each sub-basin as estimated by ArcSWAT. (a) Lamington 10 meter DEM (b) Lamington 30 meter DEM (c) Lamington 100 meter DEM. 


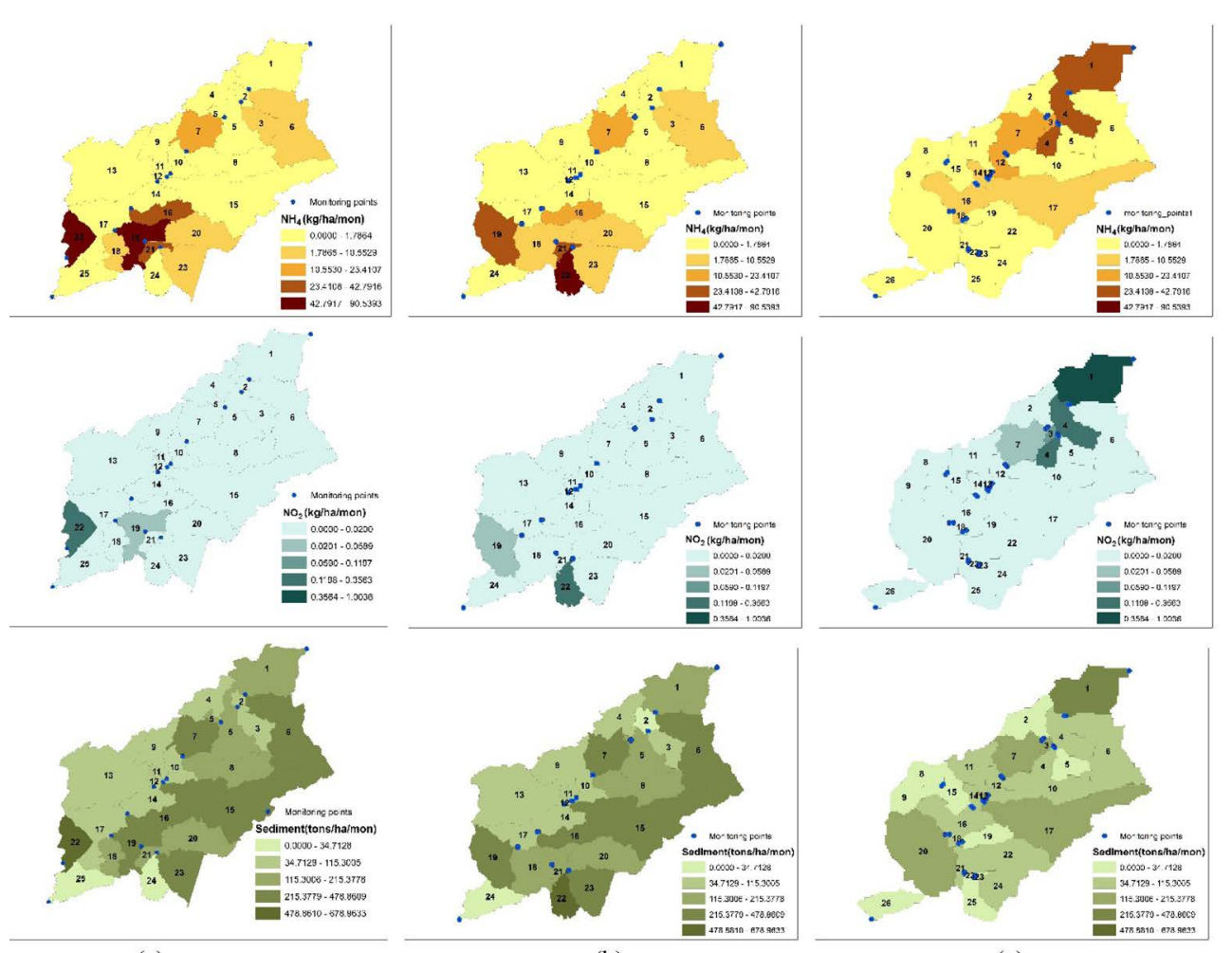

(a)

(b)

(c)

Figure 5. $\mathrm{NH}_{4}, \mathrm{NO}_{2}$ and sediment yields from each sub-basin as estimated by ArcSWAT. (a) Lawrence Brook 10 meter DEM (b) Lawrence Brook 30 meter DEM (c) Lawrence Brook 100 meter DEM.

Table 8. Effect of the 10 meter and 30 meter DEM on the prediction quality of sediment, $\mathrm{NH}_{4}$ and $\mathrm{NO}_{2}$ in Bound Brook watershed.

\begin{tabular}{|c|c|c|c|}
\hline Statistics & $100 \mathrm{~m}$ & $30 \mathrm{~m}$ & $10 \mathrm{~m}$ \\
\hline \multicolumn{4}{|l|}{ Sediment } \\
\hline Mean & 331.28 & 217.3 & 238.4 \\
\hline MD & & -163.27 & -168.96 \\
\hline MAD & & 163.32 & 169.01 \\
\hline RMSD & & 9673.16 & 9476.92 \\
\hline \multicolumn{4}{|l|}{$\mathrm{NH}_{4}$} \\
\hline Mean & 20.43 & 27.14 & 27.89 \\
\hline MD & & 0.32 & 0.46 \\
\hline MAD & & 0.32 & 0.46 \\
\hline RMSD & & 19.07 & 25.73 \\
\hline \multicolumn{4}{|l|}{$\mathrm{NO}_{2}$} \\
\hline Mean & 0.442 & 0.439 & 0.20 \\
\hline MD & & -0.00 & -0.00 \\
\hline MAD & & 0.00 & 0.00 \\
\hline RMSD & & 0.00 & 0.06 \\
\hline
\end{tabular}


Table 9. Effect of the 10 meter and 30 meter DEM on the prediction quality of sediment, $\mathrm{NH}_{4}$ and $\mathrm{NO}_{2}$ in Lamington River Watershed.

\begin{tabular}{|c|c|c|c|}
\hline Statistics & $100 \mathrm{~m}$ & $30 \mathrm{~m}$ & $10 \mathrm{~m}$ \\
\hline \multicolumn{4}{|l|}{ Sediment } \\
\hline Mean & 497.52 & 199.70 & 210.90 \\
\hline $\mathrm{MD}$ & & -201.12 & -193.56 \\
\hline MAD & & 201.19 & 193.66 \\
\hline RMSD & & $10,605.97$ & $10,212.52$ \\
\hline \multicolumn{4}{|l|}{$\mathrm{NH}_{4}$} \\
\hline Mean & 9.41 & 9.41 & 10.49 \\
\hline $\mathrm{MD}$ & & 0.02 & 0.051 \\
\hline MAD & & 0.02 & 0.05 \\
\hline RMSD & & 0.97 & 2.70 \\
\hline \multicolumn{4}{|l|}{$\mathrm{NO}_{2}$} \\
\hline Mean & 0.004 & 0.01 & 0.01 \\
\hline $\mathrm{MD}$ & & 0.00 & 0.00 \\
\hline MAD & & 0.00 & 0.00 \\
\hline RMSD & & 0.00 & 0.00 \\
\hline
\end{tabular}

Table 10. Effect of the 10 meter and 30 meter DEM on the prediction quality of sediment, $\mathrm{NH}_{4}$ and $\mathrm{NO}_{2}$ in Lawrence Brook Watershed.

\begin{tabular}{cccc}
\hline Statistics & $100 \mathrm{~m}$ & $30 \mathrm{~m}$ & $10 \mathrm{~m}$ \\
\hline Sediment & & & 56.71 \\
Mean & 77.83 & 53.54 & -3.18 \\
MD & & -4.25 & 3.18 \\
MAD & 4.25 & 175.12 \\
RMSD & & 229.06 & \\
NH ${ }_{4}$ & & & 9.037 \\
Mean & 5.194 & 8.644 & 0.05 \\
MD & & 0.04 & 0.05 \\
MAD & & 0.04 & 2.88 \\
RMSD & & 2.186 & \\
NO & & & 0.14 \\
Mean & 0.06 & 0.14 & 0.00 \\
MD & & 0.00 & 0.00 \\
MAD & 0.00 & 0.00 \\
RMSD & 0.00 & \\
\hline & & & \\
\hline
\end{tabular}

\section{Conclusions}

Simulation results over a 10 -year time period showed that runoff predictions 
vary with variation in DEM pixel size. This shows that for small watersheds with little change in topography over the area with changing resolution up to $10 \mathrm{~m}$ DEM does affect the runoff production by using the ArcSWAT. Results show that such a noticeable impact of the DEM size are important for selection of parameters in hydrological models for watersheds that are small and have smooth topography, which are known to result into low weighting in the interception, infiltration and retention [9].

In order to investigate the differences in DEM accuracy in small watersheds, research to incorporate fine resolution such as $1 \mathrm{~m}$ DEM may induce changes in the estimated outputs since the topographic parameters are computed at the HRU level which may smooth the shape of topographic features. The pixel size of the DEM is important in model sensitivity for SWAT predictions.

The scale variation in different DEMs affects the land surface and hydrological simulation. As the grid size decreases the surface area is more precisely calibrated but it can also differed by the size of the watershed and quality of the employed DEM.

This new knowledge on the impact of the DEM size on $\mathrm{NH}_{4}, \mathrm{NO}_{2}$ and sediment levels should inform researchers in optimizing parameter generation and input data preparation as well as the efficiency of SWAT model with difference in data quality. In particular, this study shows that the extra precision of DEM size is justified to obtain more accurate prediction in case of small watersheds with less variation in topography for Raritan River Basin.

These results are obtained for ArcSWAT model which is based on the definition of HRUs. These results should be applied to other watersheds and models with caution. In ArcSWAT, runoff in each HRU is calculated separately and then added up together to determine the total loadings from the sub-basin [23]. Change (increase or decrease) in HRU area may have produced different results. These results using SWAT application could be extended to other watersheds with similar environmental and hydrological conditions.

\section{Fund}

This work was supported by a USDA FS and NJAES Joint Venture: Center for Resilient Landscapes USDA-FS-14-JV-11242309-110-437485. Internal Project number 802545 .

\section{Conflicts of Interest}

The authors declare no conflicts of interest regarding the publication of this paper.

\section{References}

[1] Arnold, J.G., et al. (1998) Large Area Hydrologic Modeling and Assessment Part I: Model Development. Journal of the American Water Resources Association, 34, 73-89. https://doi.org/10.1111/j.1752-1688.1998.tb05961.x

[2] Arbab, N.N. (2014) Application of a Spatially Explicit, Agent-Based Land Use/ 
Cover Conversion Model to Assess Water Quality Outcomes under Buffer Policies, in Davis College of Agriculture, Natural Resources and Design. West Virginia University, Morgantown.

[3] Arbab, N.N., Collins, A.R. and Conley, J.F. (2016) Projections of Watershed Pollutant Loads Using a Spatially Explicit, Agent-Based Land Use Conversion Model: A Case Study of Berkeley County, West Virginia. Applied Spatial Analysis and Policy, 11, 147-181. https://doi.org/10.1007/s12061-016-9197-z

[4] Park, J.Y., Park, M.J., Joh, M.J.H.K., Shin, H.J., Kwon, H.J., Srinivasan, R. and Kim, S.J. (2011) Assessment of MIROC3.2 Hires Climate and CLUE-S Land Use Change Impacts on Watershed Hydrology Using SWAT Trans. American Society of Agricultural and Biological Engineers, 54, 1713-1724.

https://doi.org/10.13031/2013.39842

[5] Baumgart, P.D. (2005) Lower Green Bay and Lower Fox Tributary Modeling Report. Prepared for Oneida Tribe of Indians of Wisconsin and Green Bay Remedial Action Plan Science and Technical Advisory Committee of the Green Bay Remedial Action Plan (RAP).

[6] Buakhao, W. and Kangrang, A. (2016) DEM Resolution Impact on the Estimation of the Physical Characteristics of Watersheds by Using SWAT. Advances in Civil Engineering, 2016, Article ID: 8180158. https://doi.org/10.1155/2016/8180158

[7] Mutluoglu, Ö. (2010) Investigation of the Effect of Land Slope on the Accuracy of Digital Elevation Model (DEM) Generated from Various Sources. Scientific Research and Essays, 5, 1384-1391.

[8] Bolch, T. and Kamp, U. (2006) Glacier Mapping in High Mountains Using DEMs, Landsat and ASTER Data. Proceedings of the 8 th International Symposium on High Mountain Remote Sensing Cartography, Graz, 14-15 September 2006, 37-48.

[9] Chaplot, V. (2005) Impact of DEM Mesh Size and Soil Map Scale on SWAT Runoff, Sediment, and $\mathrm{NO}_{3}-\mathrm{N}$ Loads Predictions. Journal of Hydrology, 312, 207-222. https://doi.org/10.1016/j.jhydrol.2005.02.017

[10] Alansi, A.W., et al. (2009) Validation of SWAT Model for Stream Flow Simulation and Forecasting in Upper Bernam Humid Tropical River Basin, Malaysia. Hydrology and Earth System Sciences, 6, 7581-7609. https://doi.org/10.5194/hessd-6-7581-2009

[11] Thampi, S.G., Raneesh, K.Y. and Surya, T.V. (2010) Influence of Scale on SWAT Model Calibration for Streamflow in a River Basin in the Humid Tropics. Water Resources Management, 24, 4567-4578. https://doi.org/10.1007/s11269-010-9676-y

[12] Chaplot, V. (2014) Impact of Spatial Input Data Resolution on Hydrological and Erosion Modeling: Recommendations from a Global Assessment. Physics and Chemistry of the Earth, Parts A/B/C, 67-69, 23-35. https://doi.org/10.1016/j.pce.2013.09.020

[13] Lin, S., et al. (2010) Effect of DEM Resolution on SWAT Outputs of Runoff, Sediment and Nutrients. Hydrology and Earth System Sciences, 7, 4411-4435. https://doi.org/10.5194/hessd-7-4411-2010

[14] Zhang, W. (1994) Digital Elevation Model Grid Size, Landscape Representation, and Hydrologic Simulations. Water Resources Research, 30, 1019-1028. https://doi.org/10.1029/93WR03553

[15] Prodanovic, D., Stanic, M., Milivojevic, V., Simic, Z. and Arsic, M. (2009) DEMBased GIS Algorithms for Automatic Creation of Hydrological Models Data. Journal of the Serbian Society for Computational Mechanics, 3, 64-85.

[16] Cotter, A.S., et al. (2003) Water Quality Model Output Uncertainty as Affected by 
Spatial Resolution of Input Data. Journal of American Water Resources Association, 39, 977-986. https://doi.org/10.1111/j.1752-1688.2003.tb04420.x

[17] Luzio, M.D., Arnold, J.G. and Srinivasan, R. (2005) Effect of GIS Data Quality on Small Watershed Stream Flow and Sediment Simulations. Hydrological Processes, 19, 629-650. https://doi.org/10.1002/hyp.5612

[18] Dixon, B. and Earls, J. (2009) Resample or Not?! Effects of Resolution of DEMS in Watershed Modeling. Hydrological Processes, 23, 1714-1724.

https://doi.org/10.1002/hyp.7306

[19] Dehvari, A. (2014) Estimation of Surface Runoff and Sediment Yield Using WEPP Model in Southern Ontario, Canada. International Journal of Agriculture and Crop Sciences, 7, 876-889.

[20] Williams, J.R. (1995) The EPIC Model. In: Singh, V.P., Ed., Computer Models of Watershed Hydrology, Water Resources Publications, Highlands Ranch, 909-1000.

[21] Neitsch, S.L., et al. (2005) Soil and Water Assessment Tool-Theoretical Documentation-Version 2005. Grassland, Soil and Water Research Laboratory, Agricultural Research Service and Blackland Research Center, Texas Agricultural Experiment Station, Temple.

[22] Kim, J., et al. (2012) Impacts of GIS Data Quality on Determination of Runoff and Suspended Sediments in the Imha Watershed in Korea. Geosciences Journal, 16, 181-192. https://doi.org/10.1007/s12303-012-0013-8

[23] Neitsch, S.L., et al. (2002) Soil and Water Assessment Tool-User's Manual-Version 2002. Grassland, Soil and Water Research Laboratory, Agricultural Research Service and Blackland Research Center, Texas Agricultural Experiment Station, Temple, Texas. 


\section{Appendix}

(a)
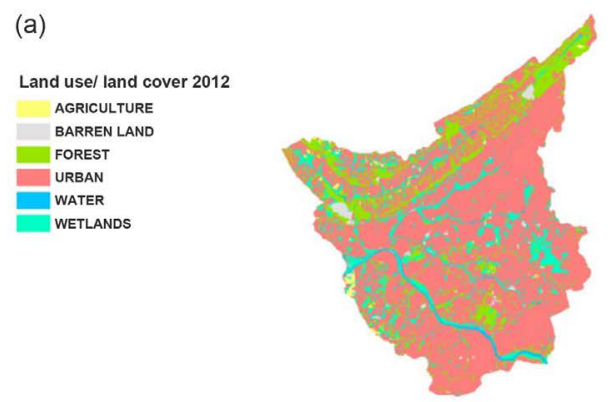

(b)
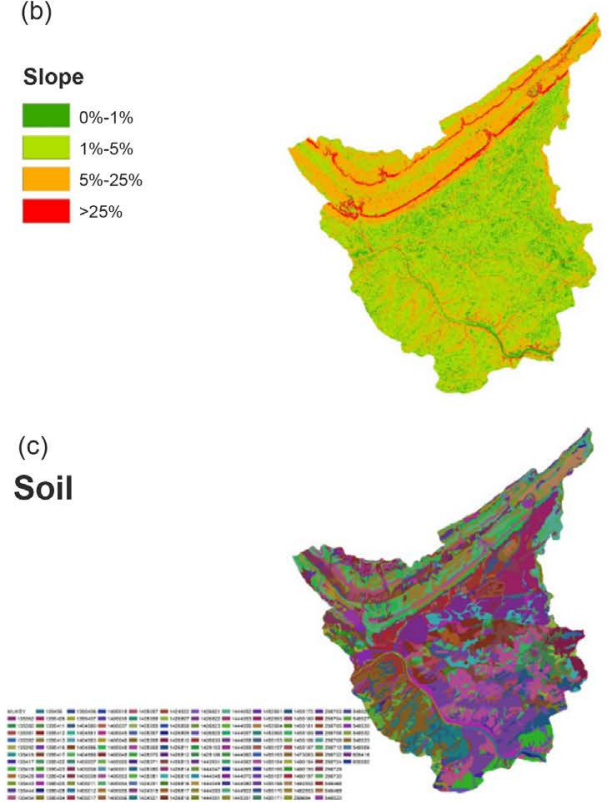

Figure A1. Bound Brook: (a) Land use/cover, (b) Slope and (c) Soil.

(a)

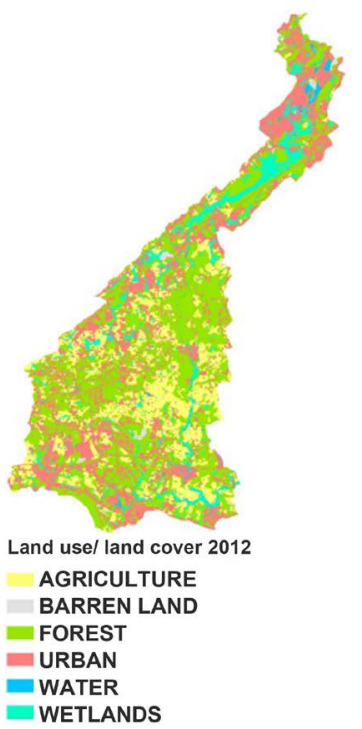

(b)

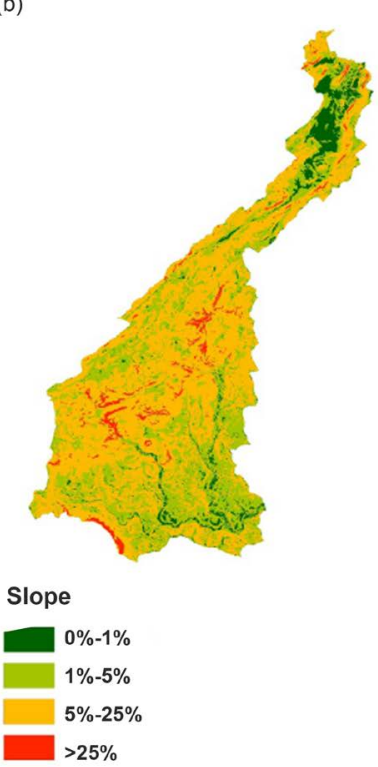

(c)

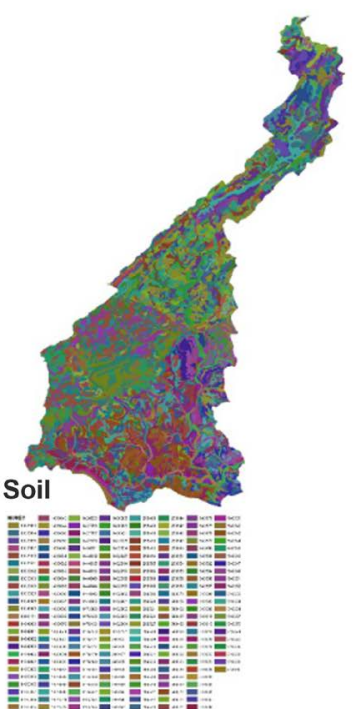

Figure A2. Lamington River: (a) Land use/cover, (b) Slope and (c) Soil. 
(a)

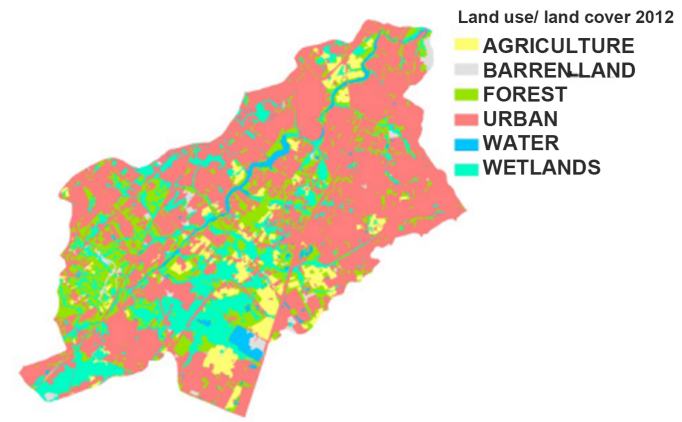

(b)

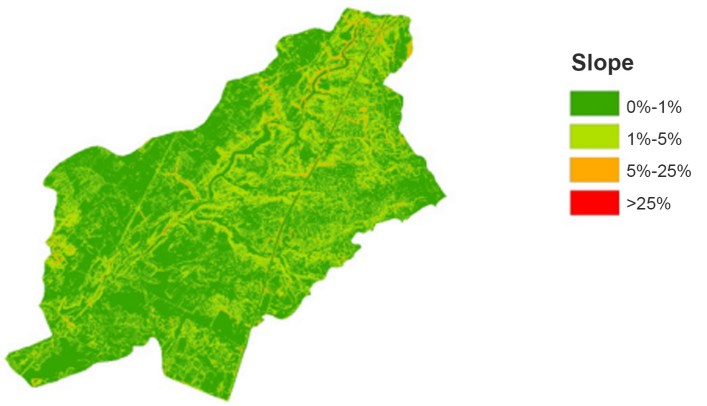

(c)

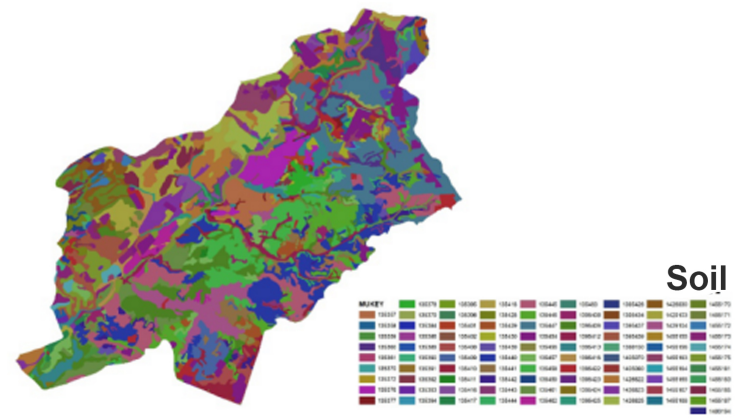

Figure A3. Lawrence Brook (a) Land use/cover, (b) Slope and (c) Soil. 